\title{
Rhodium Citrate Associated with Maghemite Nanoparticles Causes DNA Fragmentation Independently of Caspases 3 and Mediated by Reactive Oxygen Species
}

Natalia Lemos Chaves', Cláudio Afonso Pinho Lopes', Marcella Lemos Brettas Carneiro², Aparecido Ribeiro de Souza ${ }^{3}$, Matheus Oliveira da Silva ${ }^{3}$, José Raimundo Corrêa ${ }^{1}$ and Sônia Nair Báo ${ }^{\text {1*}}$

${ }^{1}$ Institute of Biological Sciences, Department of Cell Biology, University of Brasília (UnB), Brazil

${ }^{2}$ Faculty of Planaltina, University of Brasilia (UnB), Brazil

${ }^{3}$ Institute of Chemistry, Federal University of Goiás, Campus Samambaia, Goiânia, Goiás, Brazil

\begin{abstract}
Breast cancer is the most common cancer among women, excluding non-melanoma skin cancer. Research efforts have been directed towards the development of more efficient drugs against this disease, such as metal complexes, which have been widely studied. These compounds can intercalate in DNA bases and impair DNA transcription and replication, leading to cell death. Cell death can also be associated with early induction of reactive oxygen species (ROS) production by cells treated with this kind of metal complex. Nevertheless, the use of these compounds is limited because of their systemic toxicity. In this regard, the use was proposed of dirhodium citrate $\left[R h_{2}\left(H_{2} \text { cit }\right)_{4}\right]$ associated with magnetic nanoparticles (NPs), which are carriers that may work in decreasing systemic toxicity. We compared cell viability effects of free $\mathrm{Rh}_{2}\left(\mathrm{H}_{2} \mathrm{cit}\right)_{4}, \mathrm{Rh}_{2}\left(\mathrm{H}_{2} \text { cit }\right)_{4}$-loaded maghemite NPs [Magh- $\left.\mathrm{Rh}_{2}\left(\mathrm{H}_{2} \mathrm{cit}\right)_{4}\right]$ and maghemite nanoparticles loaded with citrate (Magh-cit), on MCF-7 breast cancer cells and MCF-10A non-tumor and non-tumorigenic epithelial cells by MTT assay. Furthermore, we examined whether the NPs induce cell death by apoptosis in a cell line without caspase 3 expression (MCF-7). This feature was demonstrated by quantification of ROS through labeling cells with DCFDA, DNA fragmentation studies analyzed with a flow cytometer, release of cytochrome $C$ from mitochondria assays, and effector caspases activation analysis (revealed by FLICA) as visualized by confocal microscopy. Our results confirmed that rhodium citrate was less cytotoxic in its free form than when associated with the tested drug delivery system. Moreover, Magh-Rh $\mathrm{h}_{2}\left(\mathrm{H}_{2} \text { cit }\right)_{4} \mathrm{NPs}$ and Magh-cit NPs induced apoptosis cell death mediated by ROS and independently of caspase 3 expression.
\end{abstract}

Keywords: MCF-7; Cytochrome c; Apoptosis; Breast cancer

\section{Abbreviations}

DAPI: 4',6-Diamidino-2-Phenylindolen; DCFDA: 2',7'-Dichlorofluorescin Diacetate; DMEM: Dulbecco's Modified Eagle's Medium; DMSO: Dimethyl Sulfoxide; $\mathrm{IC}_{50}$ : Inhibitory Concentration; Magh-Cit: Citrate loaded-Maghemite Nanoparticles; Magh- $\mathrm{Rh}_{2}\left(\mathrm{H}_{2} \mathrm{cit}\right)_{4}:$ Rhodium Citrate Associated with Maghemite Nanoparticles; MTT: 3-(4,5-Dimethylthiazol-2-Yl)-2,5-Diphenyltetrazolium Bromide; Nps: Nanoparticles; PBS: Phosphate-Buffered Saline; ROS: Reactive Oxygen Species; TEM: Transmission Electron Microscope; TUNEL: Terminal Deoxynucleotidyl Transferase-Mediated Dutp Nick End-Labeling

\section{Introduction}

Since metal compounds exhibit antiarthritic, antibacterial, anti-hypertensive, antidepressant and anticancer properties, these therapeutic agents have come into routine clinical use. Similarly to cisplatine, a metal compound with anticancer activity, rhodium (II) citrate has emerged as a potential antitumor agent [1]. Nevertheless, severe side effects of these treatments [2] remain a limitation and have stimulated research towards the development of delivery systems in order to improve specificity.

Nanocarriers have the potential to improve the therapeutic index of currently available drugs by increasing drug efficacy, lowering drug toxicity, and achieving steady state therapeutic levels of drugs over an extended period of time [3,4]. The association of rhodium (II) citrate with magnetic nanoparticles has the potential to increase the specificity of the cytotoxic action, since these complexes can be guided or transported to a target by the use of an external magnetic field $[5,6]$. This approach can also allow its use to produce magnetic hyperthermia [7-9]. This more specific action may have special applications in breast cancer therapy, because adverse effects of the current treatments and remission risk are prominent issues. Furthermore, the high mortality rates and severity of this problem make novel therapy investigations urgent [10-12].

Metals or reactive oxygen species (ROS) generated by metals in the cells can directly initiate the intrinsic apoptotic pathway at the mitochondria or indirectly trigger this pathway by p53 activation as a result of DNA damage induced by metal or ROS $[13,14]$. The p53 activation leads to the expression of Bax and Noxa, two proapoptotic proteins which induce an increase in mitochondrial permeability [15]. In this circumstance, cytochrome $\mathrm{C}$ is released into the cytosol from damaged mitochondria and binds to Apaf1, resulting in caspases activation $[16,17]$.

Apoptosis regulation defects are the main factors that contribute to carcinogenesis and cancer progression. These problems also figure prominently in the resistance to chemotherapy, radiotherapy, hormonal therapy and immune-based treatments $[18,19]$. Currently,

*Corresponding author: Sônia Nair Báo, Institute of Biological Sciences Department of Cell Biology, University of Brasília (UnB), Brazil, Tel: +556131073300; E-mail:snbao@unb.br

Received June 06, 2015; Accepted July 20, 2015; Published July 30, 2015

Citation: Chaves NL, Lopes CAP, Carneiro MLB, Souza ARD, Silva MOD, et al (2015) Rhodium Citrate Associated with Maghemite Nanoparticles Causes DNA Fragmentation Independently of Caspases 3 and Mediated by Reactive Oxygen Species. J Nanomed Nanotechnol 6: 312. doi:10.4172/2157-7439.1000312

Copyright: (c) 2015 Chaves NL, et al. This is an open-access article distributed under the terms of the Creative Commons Attribution License, which permits unrestricted use, distribution, and reproduction in any medium, provided the original author and source are credited. 
Citation: Chaves NL, Lopes CAP, Carneiro MLB, Souza ARD, Silva MOD, et al. (2015) Rhodium Citrate Associated with Maghemite Nanoparticles Causes DNA Fragmentation Independently of Caspases 3 and Mediated by Reactive Oxygen Species. J Nanomed Nanotechnol 6: 312. doi:10.4172/2157-7439.1000312

it is recognized that many efficient chemotherapeutics act by triggering any of the apoptosis pathways [20]. Depending on the involvement of different caspases activation mechanisms, cell death by apoptosis can be roughly divided into two categories: (1) receptor mediated 'extrinsic' apoptosis (death ligands with caspase 8 activation) and (2) mitochondria-mediated 'intrinsic' apoptosis (cytochrome $\mathrm{C}$ release and caspase 9 activation) [21]. Both types of apoptosis induction pathway converge to the activation of the same effector caspases, mainly caspase 3 , in order to complete the apoptotic process $[16,22]$.

Caspase 3 has been considered essential for certain processes associated with the dismantling of the cell and the formation of apoptotic bodies. This caspase is activated after barrier mitochondrial membrane rupture [23]. By the proteolysis of substrates, caspase 3 mediates some of the typical morphological and biochemical changes associated with apoptosis, such as the cleavage of a-fodrin, gelsolin, kinase-associated rho-1 (ROCK-1) and p21-activated kinase 2 (PAK2), which contribute to membrane blebbing [24], cleavage of the inhibitor of caspase-activated DNAse (ICAD) and lead to the pattern of DNA fragmentation typically observed in apoptosis $[25,26]$.

The MCF-7 cells do not express caspase 3. Despite this, MCF7 cells can exhibit morphological changes consistent with apoptosis, including DNA fragmentation, following treatment with a variety of agents and conditions [27]. Thus, it was suggested that caspase 3 may not be essential for DNA fragmentation during apoptosis in some instances $[28,29]$. It has already been suggested that rhodium citrate could induce apoptosis in MCF-7 cells [30]. However, this induction was not confirmed when the association of rhodium citrate with maghemite NPs was employed, and the mechanism of this process is not clear.

In the present study, we investigated cell death by apoptosis induced by rhodium (II) citrate loaded-maghemite nanoparticles in MCF-7 breast cancer cells, with special consideration for the dependence of caspase 3 and ROS as mediators.

\section{Materials and Methods}

\section{Nanoparticles}

The magnetic fluids used were synthesized by the co-precipitation method of $\mathrm{Fe}^{+2}$ and $\mathrm{Fe}^{+3}$ ions in alkaline medium and subsequently oxidized by bubbling oxygen. The functionalized fluids of rhodium citrate associated with maghemite nanoparticles [Magh- $\mathrm{Rh}_{2}\left(\mathrm{H}_{2} \mathrm{cit}_{4}\right)$ ] and citrate loaded-maghemite nanoparticles, Magh-cit, were obtained by adsorption experiments [31]. Magh- $\mathrm{Rh}_{2}\left(\mathrm{H}_{2} \mathrm{cit}_{4}\right)$ with $2 \times 10^{16}$ particles $/ \mathrm{ml}$, Magh-cit with $2.13 \times 10^{16}$ particles $/ \mathrm{ml}$ and $2.513 \mathrm{mM}$ $\mathrm{Rh}_{2}\left(\mathrm{H}_{2} \mathrm{cit}_{4}\right)$ were synthesized and characterized at the Institute of Chemistry of Goiás Federal University (UFG, Goiânia, GO, Brazil).

Rhodium (II) citrate $\left[\mathrm{Rh}_{2}\left(\mathrm{H}_{2} \mathrm{cit}\right)_{4}\right]$ and rhodium (II) citrate associated with maghemite nanoparticles [Magh- $\left.\mathrm{Rh}_{2}\left(\mathrm{H}_{2} \mathrm{cit}\right)_{4}\right]$ were used at concentrations of $50 \mu \mathrm{M}, 200 \mu \mathrm{M}$ and $300 \mu \mathrm{M}$ of rhodium citrate, whilst maghemite nanoparticles functionalized with citrate (Magh-cit) were employed at concentrations of $3 \mathrm{mM}, 12 \mathrm{mM}$ and 19 $\mathrm{mM}$ of iron in order to contain the same iron concentrations in the Magh- $\mathrm{Rh}_{2}\left(\mathrm{H}_{2} \mathrm{cit}\right)_{4}$ final solutions.

\section{Cell culture}

The human breast cancer cell line MCF-7 was obtained from the American Type Culture Collection (ATCC) and cultured in Dulbecco's modified Eagle's medium containing 1\% (v/v) penicillin-streptomycin (Sigma-Aldrich, St Louis, MO, USA) and 10\% (v/v) heat-inactivated fetal bovine serum (FBS, Gibco, Life Technologies, Carlsbad, CA, USA). Human normal breast cell line MCF-10A (donated by Dr. Maria Mitzi Brentani, University of São Paulo, Brazil) was cultured with a 1:1 mixture of DMEM and F12 medium (Sigma-Aldrich, St Louis, MO, USA) supplemented with $5 \%$ horse serum (Gibco, Life Technologies, Carlsbad, CA, USA), hydrocortisone $(0.5 \mu \mathrm{g} / \mathrm{ml}$, Sigma-Aldrich, St Louis, MO, USA), insulin ( $1 \mathrm{mg} / \mathrm{ml}$, Sigma, USA), epidermal growth factor $(20 \mathrm{ng} / \mathrm{ml}$, Sigma-Aldrich, St Louis, MO, USA), choleric toxin (100 ng/ml; Sigma-Aldrich, St Louis, MO, USA) and $1 \%(\mathrm{v} / \mathrm{v})$ penicillin-streptomycin (Sigma-Aldrich, St Louis, MO, USA). The cells were maintained in a $5 \% \mathrm{CO}_{2}$ humidified incubator at $37^{\circ} \mathrm{C}$. At $85 \%$ confluence, cells were harvested using $0.25 \%$ trypsin (Gibco, Life Technologies, Carlsbad, CA, USA) and were subcultured in $75 \mathrm{~cm}^{2}$ flask or 6,12 or 96 -well plate according to the experimental procedures. The cells were allowed to attach to the surface for 24 hours prior to the treatments. The $\mathrm{Rh}_{2}\left(\mathrm{H}_{2} \mathrm{cit}\right)_{4} \mathrm{Magh}-\mathrm{Rh}_{2}\left(\mathrm{H}_{2} \mathrm{cit}\right)_{4}$ and Maghcit nanoparticles were suspended in cell culture medium, diluted to the defined concentrations and then added to the attached cells for the time required in each experiment.

\section{Nanoparticles characterization}

The diameter distribution and surface charge of the nanoparticles were analyzed by using the Zetasizer Nano ZS machine (Malvern, Malvern,UK).

The assay was performed at $25^{\circ} \mathrm{C}$ with nanoparticles from the stock solutions [Magh- $\mathrm{Rh}_{2}\left(\mathrm{H}_{2} \mathrm{cit}\right)_{4}$ with $2 \times 10^{16}$ iron particles $/ \mathrm{ml}$ and Maghcit with $2.13 \times 10^{16}$ iron particles per $\mathrm{ml}$ at the dilution of 1:1000 in ultrapure water.

\section{Transmission electron microscopy}

Morphology and size of the nanoparticles were evaluated by transmission electron microscopy (TEM). The stock solutions of Magh- $\mathrm{Rh}_{2}\left(\mathrm{H}_{2} \text { cit }\right)_{4}$ and Magh-cit were diluted 1:100 and deposited on 300 -mesh grids coated with formvar-carbon film and dried at room temperature. Subsequently, nanoparticles were observed under a JEM-1011 transmission electron microscope (JEOL, Tokyo, Japan) operating at $100 \mathrm{kV}$, and the images were acquired by an Ultrascan camera (Gatan, Pleasanton). Nanoparticles $(n=120)$ were measured by using the Image Pro-Plus 5.1 software, and data were adjusted by log normal distribution in a Gaussian curve in order to obtain the modal diameter.

\section{MTT assay}

In order to understand how cells respond to Magh- $\mathrm{Rh}_{2}\left(\mathrm{H}_{2} \mathrm{cit}\right)_{4}$ nanoparticles, MCF-7 cells were incubated for $24 \mathrm{~h}$ with various concentrations of this compound. Furthermore, the tumor cells were also exposed to free rhodium citrate and maghemite nanoparticles at the same concentrations as those in Magh- $\mathrm{Rh}_{2}\left(\mathrm{H}_{2} \mathrm{cit}\right)_{4}$. The MCF-10A non-tumor cells were used to assess effects of the treatments on normal cells.

Viability of MCF-7 and MCF10-A cells after exposure to NPs and $\mathrm{Rh}_{2}\left(\mathrm{H}_{2} \mathrm{cit}\right)_{4}$ was evaluated by the MTT assay according to the manufacturer's recommendations (Invitrogen, Life Technologies, Carlsbad, CA, USA). Briefly, $1 \times 10^{4}$ cells/well were seeded in 96-well plates and exposed to the treatments at the concentrations of $50 \mu \mathrm{M}$, $200 \mu \mathrm{M}, 300 \mu \mathrm{M}$ (rhodium citrate) or $3 \mathrm{mM}, 12 \mathrm{mM}$ and $19 \mathrm{mM}$ (iron) for $24 \mathrm{~h}$. All experiments were repeated at least three times in triplicates. Results were expressed as percent of viability $(\% \mathrm{~V})$ according to the following formula (blank discounted): $\% \mathrm{~V}=$ absorbance (cells + medium + NPs) - absorbance (medium + NPs). After cell treatment, 
Citation: Chaves NL, Lopes CAP, Carneiro MLB, Souza ARD, Silva MOD, et al. (2015) Rhodium Citrate Associated with Maghemite Nanoparticles Causes DNA Fragmentation Independently of Caspases 3 and Mediated by Reactive Oxygen Species. J Nanomed Nanotechnol 6: 312. doi:10.4172/2157-7439.1000312

the medium was removed from each well and replaced with new medium containing MTT $(15 \mu \mathrm{L}$ of MTT solution at $5 \mathrm{mg} / \mathrm{ml}$ and 135 $\mu \mathrm{L}$ of culture medium) for two and a half hours at $37^{\circ} \mathrm{C}$ in humidified atmosphere with $5 \% \mathrm{CO}_{2}$. The resulting formazan product was dissolved in $200 \mu \mathrm{L}$ of dimethyl sulfoxide (DMSO, Sigma-Aldrich, St Louis, MO, USA). Afterwards, the supernatants of each sample were transferred to a fresh 96-well plate (to avoid the interference of nanoparticles that did not enter the cells and accumulate at the bottom of the wells) and absorbance was measured by a spectrophotometer (SpectraMax M2, Molecular Devices, Sunnyvale, CA, USA) at the $595 \mathrm{~nm}$ wavelength.

\section{Laser scanning confocal microscopy analyses}

Cytochrome Clocation, DNA fragmentation assessment by TUNEL and caspases 6 and 7 detection were performed by using laser scanning confocal microscopy. MCF-7 cells $\left(2 \times 10^{5}\right)$ were seeded onto glass coverslips placed in the bottom of 24-well plates and treated with Magh$\mathrm{Rh}_{2}\left(\mathrm{H}_{2} \mathrm{cit}\right)_{4}(300 \mu \mathrm{M})$ and Magh-cit (19 $\mu \mathrm{M}$ Iron). Afterwards, for DNA fragmentation and cytochrome $\mathrm{C}$ location analyses, cells were washed twice with PBS, fixed in $4 \%$ paraformaldehyde and permeabilized with $0.1 \%$ Triton X-100 in $0.1 \%$ sodium citrate. Thereafter, for DNA fragmentation evaluation, cells were incubated with fluorescein-tagged dUTP in the presence of terminal deoxynucleotidyl transferase (Roche Applied Science, Indianapolis, IN, USA) for one hour in the dark. In the other examination, MCF-7 cells were blocked by incubation for $2 \mathrm{~h}$ in PBS buffer containing 3\% fetal bovine serum, incubated with anti-cytochrome C (1:200; Invitrogen, Life Technologies, Carlsbad, CA, USA) for two hours, washed with PBS and incubated with a secondary antibody conjugate (Alexa-fluor 488 from Invitrogen, Life Technologies, Carlsbad, CA, USA) and red mitotracker (Invitrogen, Life Technologies, Carlsbad, CA, USA) for cytochrome C location analysis. The cells were also incubated with DAPI $(0.5 \mathrm{~g} / \mathrm{ml})$ for nuclei staining. For the caspases $3 / 7$ and 6 activity assay, the apoptosis detection kits from Immunochemistry Technologies (Bloomington, MN, USA) were used according to the manufacturer's instructions. These caspase detection probes are comprised of an affinity peptide inhibitor sequence, a fluoromethyl ketone (FMK) moiety that facilitates an irreversible binding event with the activated caspase enzyme, and a fluorescent tag reporter. The cells were incubated with the Fluorescent Labeled Inhibitor of Caspases 3/7 (FLICA-SR) and caspase 6 (FLICAFAM) and maintained for $1 \mathrm{~h}$ at $37^{\circ} \mathrm{C}$ in a $\mathrm{CO}_{2}$ incubator. Subsequently, the Hoechst stain was used to label the nuclei $(200 \mu \mathrm{g} / \mathrm{ml})$. The cells were washed twice (wash buffer) and fixed with a formaldehyde fixative solution (1:10) in wash solution. Coverslips were then mounted onto microscope slides using an anti-fade mounting medium, and incubated at $4^{\circ} \mathrm{C}$ in the dark. All assays described above were analyzed on a laser scanning confocal microscope Leica TCS-SP5 (Leica, Mannheim, DE).

\section{Measurement of reactive oxygen species (ROS)}

Reactive oxygen species generation was measured by staining MCF-7 cells with 5-(and-6) carboxy-2', $7^{\prime}$-dichlorodihydrofluorescein diacetate (DCFDA, Sigma-Aldrich, St Louis, MO, USA). Cells were exposed to Magh- $\mathrm{Rh}_{2}\left(\mathrm{H}_{2} \mathrm{cit}\right)_{4}(300 \mu \mathrm{M})$ or Magh-cit $(19 \mu \mathrm{M}$ iron) for $1.5 \mathrm{~h}$, then medium was discarded and cells were washed with PBS and incubated with $20 \mu \mathrm{M}$ DCFDA in culture medium without phenol red under low-light conditions. The cells were incubated for $30 \mathrm{~min}$ at $37^{\circ} \mathrm{C}$ and the fluorescence emission (excitation at $488 \mathrm{~nm}$ and fluorescence emission at $535 \mathrm{~nm}$ ) from DCFDA was analyzed by using a plate reader (SpectraMax M2, Molecular Device) and laser scanning confocal microscope Leica TCS-SP5 (Leica). Hydrogen peroxide (100 mM for $20 \mathrm{~min}$ ) was used as positive control in order to validate the protocol.

\section{Flow cytometry analysis}

The flow cytometry analysis was performed in order to determine the percentage of DNA fragmentation. MCF-7 cells $\left(1 \times 10^{6}\right)$, after treatment with nanoparticles [300 $\mathrm{MM}$ Magh- $\mathrm{Rh}_{2}\left(\mathrm{H}_{2} \mathrm{cit}\right)_{4}$ or $19 \mu \mathrm{M}$ (iron) in Magh-cit], were harvested by centrifugation, washed with PBS, and re-suspended in $100 \mu \mathrm{l}$ PBS containing $50 \mu \mathrm{g} / \mathrm{ml}$ RNAse. After incubation at $37^{\circ} \mathrm{C}$ for $1 \mathrm{~h}$, cells were permeabilized with triton $\mathrm{X}-100$ solution $(0.1 \%$ citrate and $1 \%$ triton $\mathrm{X}-100$ in PBS), and then stained with PI $(100 \mu \mathrm{g} / \mathrm{ml}$, Sigma, USA $)$ at $4^{\circ} \mathrm{C}$ for $30 \mathrm{~min}$ in the dark. The cell samples $\left(1 \times 10^{6}\right)$ were re-suspended in $100 \mu \mathrm{PBS}$ and analyzed in a CyFlow space cytometer (Partec, Münster, DE).

\section{Statistical analysis}

Values are expressed as the mean \pm standard error of the mean. Each value is the mean of at least three independent experiments with each group. Comparisons of treatments against controls, the effects of exposure time and concentration of maghemite nanoparticles were made by using two-way analysis of variance (ANOVA) followed by Bonferroni's post hoc test. One-way analysis of variance (ANOVA) followed by Tukey's multiple post hoc comparison were used to evaluate intracellular reactive oxygen species production. All analyses were performed with the GraphPad Prism (v. 4) software. The asterisks $\left(^{*}\right)$ indicate that values are significant $\left({ }^{*} \mathrm{p}<0.05\right.$, ${ }^{* *} \mathrm{p}<0.01$ and $\left.{ }^{* *} \mathrm{p}<0.001\right)$.

\section{Results}

\section{Characterization of the nanoparticles}

The Magh- $\mathrm{Rh}_{2}\left(\mathrm{H}_{2} \mathrm{cit}\right)_{4}$ nanoparticles analyzed by TEM (Figure $1 \mathrm{~A}$ ) exhibited a modal diameter of 7-8 $\mathrm{nm}$. They were larger than Maghcit nanoparticles (Figure 1B), for which the most frequent diameter range was 5-6 $\mathrm{nm}$. The hydrodynamic diameter (Figure $2 \mathrm{~A}$ ) was also higher in Magh- $\mathrm{Rh}_{2}\left(\mathrm{H}_{2} \mathrm{cit}\right)_{4}$ nanoparticles $(160.8 \mathrm{~nm})$ compared to Magh-cit $(107 \mathrm{~nm})$. Furthermore, the zeta-potential of Magh-cit and Magh- $\mathrm{Rh}_{2}\left(\mathrm{H}_{2} \mathrm{cit}\right)_{4}$ nanoparticles in water $(1: 1000)$ was $-48 \mathrm{mV}$ and $-57.6 \mathrm{mV}$, respectively (Figure $2 \mathrm{~B}$ ). The polydispersity index (PDI) was $0.137 \pm 0.011$ for Magh-cit and $0.118 \pm 0.013$ for Magh- $\mathrm{Rh}_{2}\left(\mathrm{H}_{2} \mathrm{cit}\right)_{4}$ nanoparticles (Figure 2B).

\section{Cytotoxicity induced by Magh- $\mathrm{Rh}_{2}\left(\mathrm{H}_{2} \mathrm{cit}\right)_{4}$, Magh-cit nanoparticles and $\mathrm{Rh}_{2}\left(\mathrm{H}_{2} \mathrm{cit}\right)_{4}$}

A decrease was observed in cell viability induced by the drug and nanoparticles in a dose-dependent manner (Figure 3). The $\mathrm{Rh}_{2}\left(\mathrm{H}_{2} \text { cit }\right)_{4}$ treatment did not significantly reduce the viability of tumor cells at concentrations of up to $300 \mu \mathrm{M}$, while a decrease of viable MCF-7 cells treated with nanoparticles at the concentrations of $200 \mu \mathrm{M}$ was observed (Figure 3). The combination of the free drug $\left(\mathrm{Rh}_{2}\left(\mathrm{H}_{2} \mathrm{cit}\right)_{4}\right)$ at the same concentrations with nanoparticles [Magh-Rh ${ }_{2}\left(\mathrm{H}_{2} \mathrm{cit}\right)_{4}$ ] enhanced cytotoxic potency. After $24 \mathrm{~h}$ of employment of the highest concentrations of $\mathrm{Magh}-\mathrm{Rh}_{2}\left(\mathrm{H}_{2} \mathrm{cit}\right)_{4}$, which contained 200 or $300 \mu \mathrm{M} \mathrm{Rh}_{2}\left(\mathrm{H}_{2} \mathrm{cit}\right)_{4}$ and 12 and $19 \mathrm{mM}$ (iron content respectively), percentages of viable MCF-7 cells (Figure 3) were significantly reduced ( $58 \%$ and $38 \%$, respectively). On the other hand, cell viability was also significantly affected in MCF-7 cells after $24 \mathrm{~h}$ of incubation with an equivalent concentration of iron $(19 \mathrm{mM})$ in Magh-cit. This treatment reduced MCF-7 cells viability to $51 \%$ in comparison to the control (Figure 3). Due to these results, the Magh-cit treatment was included in the following tests. None of the compounds assayed significantly reduced MCF-10A cell viability with various concentrations. We determined the treatment concentration of $300 \mu \mathrm{M}$ 
Citation: Chaves NL, Lopes CAP, Carneiro MLB, Souza ARD, Silva MOD, et al. (2015) Rhodium Citrate Associated with Maghemite Nanoparticles Causes DNA Fragmentation Independently of Caspases 3 and Mediated by Reactive Oxygen Species. J Nanomed Nanotechnol 6: 312. doi:10.4172/2157-7439.1000312
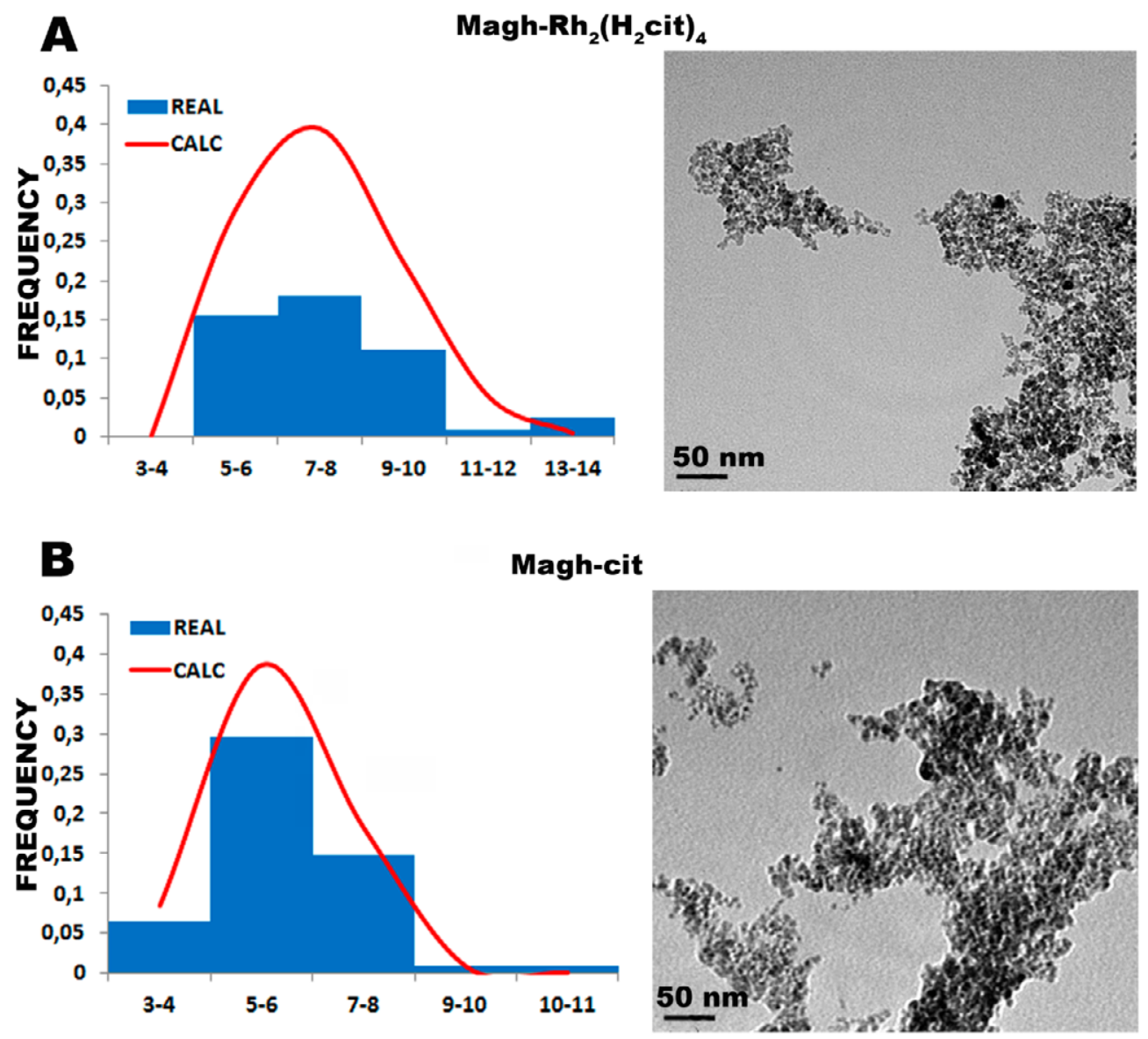

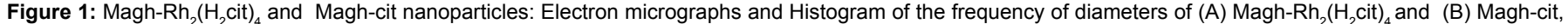
showing a modal diameter of 7-8 $\mathrm{nm}$ and 5-6 nm, respectively.

A

Magh-Rh ${ }_{2}\left(\mathbf{H}_{2} \mathbf{c i t}\right)_{4}$

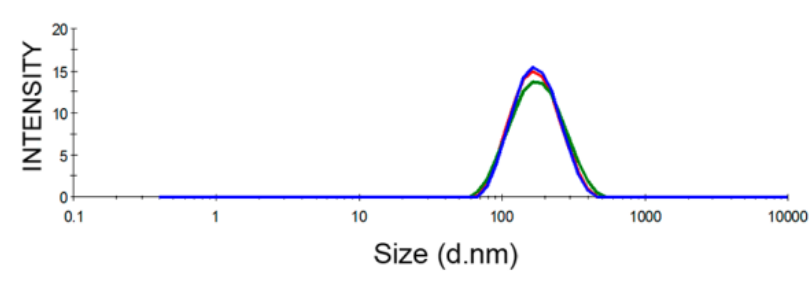

B

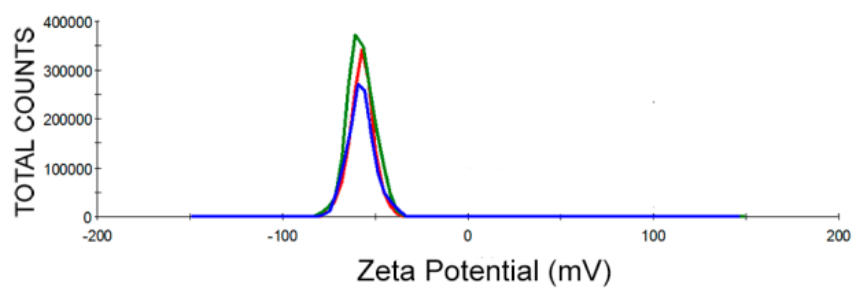

Magh-cit
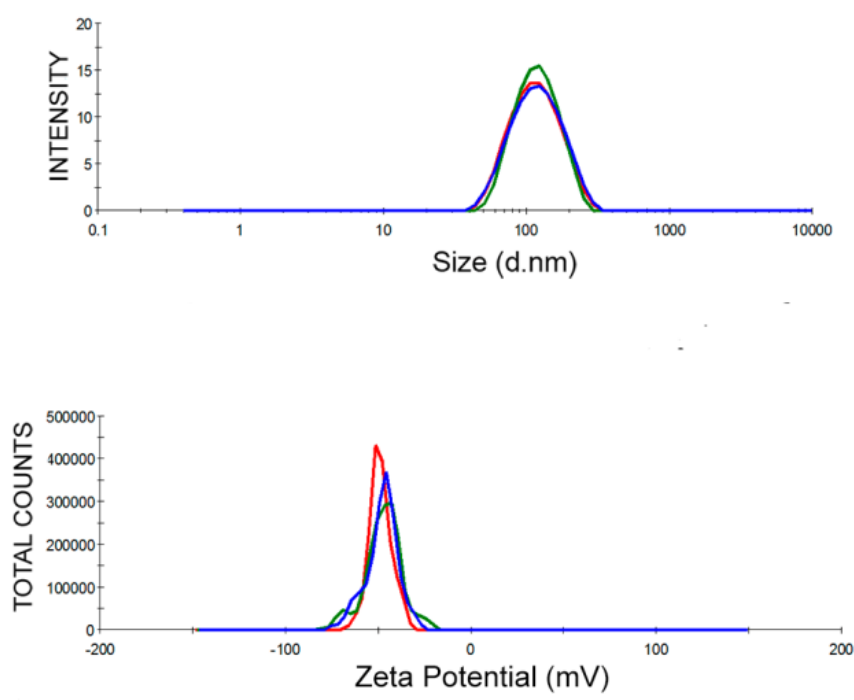

Figure 2: Nanoparticles characterization: (A) Size intensity of Magh-Rh ${ }_{2}\left(\mathrm{H}_{2} \text { cit }\right)_{4}$ and Magh-cit. (B) Zeta potential distributions of Magh-Rh $\left(\mathrm{H}_{2} \mathrm{cit}\right)_{4}$ and Magh-cit. 
Citation: Chaves NL, Lopes CAP, Carneiro MLB, Souza ARD, Silva MOD, et al. (2015) Rhodium Citrate Associated with Maghemite Nanoparticles Causes DNA Fragmentation Independently of Caspases 3 and Mediated by Reactive Oxygen Species. J Nanomed Nanotechnol 6: 312. doi:10.4172/2157-7439.1000312

Page 5 of 10

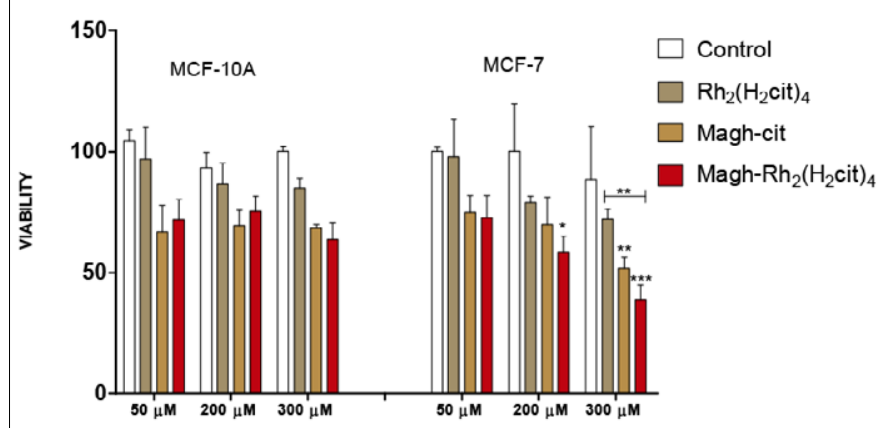

Notes: All results are the means of three sets of experiments; error bars represent the standard error of the mean (two-way analysis of variance (ANOVA) followed by the Bonferroni's post hoc test). ${ }^{*} P<0.05 ;{ }^{* *} P<0.01$ $P<0.001$.

Figure 3: Viability of MCF-7 and MCF10-A cells : Cell viability in human MCF-10A mammary epithelial cells and MCF-7 breast cancer after 24 hours treatment with: free Rhodium (II) citrate $\left(\mathrm{Rh}_{2}\left(\mathrm{H}_{2} \mathrm{cit}\right)_{4}\right) ; \mathrm{Rh}_{2}\left(\mathrm{H}_{2} \mathrm{cit}\right)_{4}$ associated with maghemite nanoparticles (Magh- $\mathrm{Rh}_{2}\left(\mathrm{H}_{2} \mathrm{cit}\right)_{4}$, (containing $0.153 \mathrm{~mol} / \mathrm{L}$ iron) at the concentrations of $50 \mu \mathrm{M}, 200 \mu \mathrm{M}$ and $300 \mu \mathrm{M}$; or citrate-loaded maghemite (Magh-cit) nanoparticles at the concentrations of $3 \mathrm{mM}, 12 \mathrm{mM}$ and $19 \mathrm{mM}$ (iron).

for the other tests from the calculation of $\mathrm{IC}_{50}$ for MCF-7 tumor cells $\left[\mathrm{IC}_{50}\right.$ Magh- $\left.\mathrm{Rh}_{2}\left(\mathrm{H}_{2} \mathrm{cit}\right)_{4}=312,1\right]$.

\section{Estimation of intracellular ROS induced by Magh- $\mathrm{Rh}_{2}\left(\mathrm{H}_{2} \mathrm{cit}\right)_{4}$} and Magh-cit nanoparticles

In order to evaluate the oxidative stress induced by maghemite nanoparticles, the ROS production was quantified in treated tumor cell samples. After one and a half hours, a significant increase was observed in ROS production in MCF-7 cells induced by Magh- $\mathrm{Rh}_{2}\left(\mathrm{H}_{2} \text { cit }\right)_{4}$ treatment, as compared to the control samples and samples treated with Magh-cit. The ROS quantification was estimated by DCFDA fluorescence intensity (Figure 4).

Magh- $\mathrm{Rh}_{2}\left(\mathrm{H}_{2} \mathrm{cit}\right)_{4}$ and Magh-cit nanoparticles alter mitochondrial membrane potential causing cytochrome $\mathbf{C}$ release

This analysis aimed to determine cytochrome $\mathrm{c}$ activation and translocation in MCF-7 cells. In cell samples treated with $10 \mathrm{nM}$ paclitaxel for two hours (Figures 5A-C), the cytochrome C labeling (green) predominated over the mitochondrial tag (red). This feature is better shown in the overlay images (Figure 5C). This pattern suggests that the proteins are no longer confined within mitochondria. In untreated cell samples (Figures 5D-F), cytochrome C labeling coincides with mitochondria labeling, showing a merged fluorescent yellow in the overlay images (Figure 5F). The yellow color means that cytochrome $\mathrm{C}$ localization is the same as that of the mitochondria. In the groups of cells treated with $300 \mu \mathrm{M} \mathrm{Rh}\left(\mathrm{H}_{2} \text { cit }\right)_{4}$-loaded maghemite NPs [Magh- $\mathrm{Rh}_{2}\left(\mathrm{H}_{2} \mathrm{cit}\right)_{4}$ ] (Figures 5G-I) or $0.019 \mathrm{~mol} / \mathrm{L}$ (iron) maghemite nanoparticles loaded with citrate (Magh-cit) for 24 hours, the results were similar to those already described for the positive control comprising cells treated with paclitaxel. Therefore, it is suggested that both of these test treatments were able to induce the release of cytochrome $\mathrm{C}$ into the cytoplasm in MCF-7 cells (Figures 5J-L).

Magh- $\mathrm{Rh}_{2}\left(\mathrm{H}_{2} \mathrm{cit}\right)_{4}$ and Magh-cit induced caspases 6 and 7 activation in MCF-7 cells

Effector caspases 6 and 7 were present in active forms after 12 hours of treatment with Magh- $\mathrm{Rh}_{2}\left(\mathrm{H}_{2} \mathrm{cit}\right)_{4}$ and Magh-cit (Figures 6A-I). The fluorescent labeling of caspases was accompanied by the occurrence of pyknotic nucleus (revealed by DAPI labeling), which is another key feature observed in apoptotic cells (Figures 6A-I). The control cells (untreated) showed no labeling of activated caspases. When both caspases were labeled simultaneously in the cells treated with the two compounds, it was observed that the two caspases are activated at the same time.

\section{Magh- $\mathrm{Rh}_{2}\left(\mathrm{H}_{2} \mathrm{cit}\right)_{4}$ and Magh-cit induced apoptosis with DNA fragmentation in MCF-7 cells}

In order to analyze whether Magh- $\mathrm{Rh}_{2}\left(\mathrm{H}_{2} \mathrm{cit}\right)_{4}$ and Magh-cit nanoparticles promote cell death with DNA fragmentation in MCF-7 cells, despite the absence of activated caspase 3 , flow cytometry and laser scanning confocal microscopy of TUNEL-labeled cells were performed. In the flow cytometry analysis, it was observed that the nanoparticles induced DNA fragmentation in MCF-7 cells (Figures 7A and B), which was significantly higher than that in the control cells after 36 hours of the stimulus with $300 \mu \mathrm{M}$ Magh- $\mathrm{Rh}_{2}\left(\mathrm{H}_{2} \mathrm{cit}\right)_{4}$ or $19 \mathrm{mM}$ (iron) Maghcit. However, no statistical difference was observed between these two treatments, which displayed TUNEL labeling profiles similar to that of the positive control (Figure 7C).

\section{Discussion}

In this work, we confirmed that the association of maghemite nanoparticles and rhodium citrate enhances their effects on breast cancer cells in a more specific way. This enhancement process observed with drug association to nanostructures is widely described by other authors [31-33]. Moreover, even in the absence of the associated drug, maghemite nanoparticles containing only citrate can promote damage to tumor cells, once again in a specific manner as compared
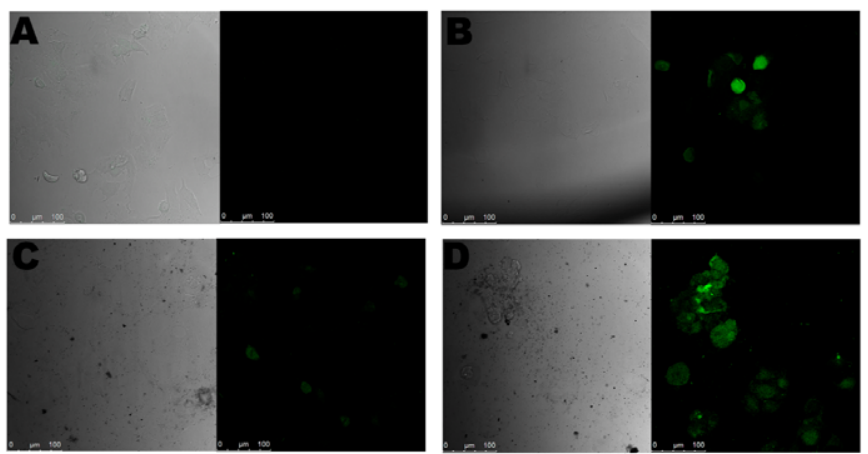

$\mathbf{E}$

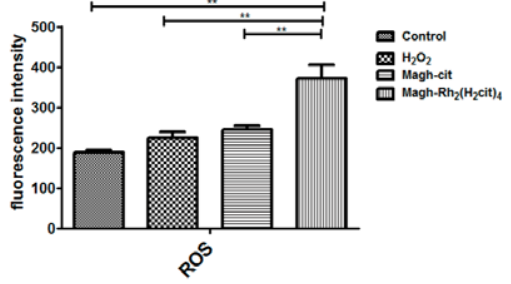

Notes: Scale bars: $100 \mu \mathrm{M}$

Figure 4: Effects of nanoparticles on ROS levels in breast cancer cells : The control group consisted of untreated cells $(A)$. Hydrogen peroxide $(100 \mathrm{mM}$ for $20 \mathrm{~min}$ ) was used as positive control (B). The cells (MCF-7) were treated with $0.019 \mathrm{~mol} / \mathrm{L}$ (iron) maghemite nanoparticles loaded with citrate (Magh-cit) (C) or $300 \mu \mathrm{M} \mathrm{Rh}{ }_{2}\left(\mathrm{H}_{2} \text { cit }\right)_{4}$-loaded maghemite NPs [Magh-Rh $\mathrm{H}_{2}\left(\mathrm{H}_{2} \mathrm{cit}\right)_{4}$ ] (D) for $\left.1.5 \mathrm{~h}\right)$. Intracellular ROS levels were measured by DCFDA fluorescence intensity (E). ${ }^{* *} p<0.01$, compared with the untreated control group using One-way analysis of variance (ANOVA) followed by Tukey's multiple post hoc comparison. 
Citation: Chaves NL, Lopes CAP, Carneiro MLB, Souza ARD, Silva MOD, et al. (2015) Rhodium Citrate Associated with Maghemite Nanoparticles Causes DNA Fragmentation Independently of Caspases 3 and Mediated by Reactive Oxygen Species. J Nanomed Nanotechnol 6: 312. doi:10.4172/2157-7439.1000312

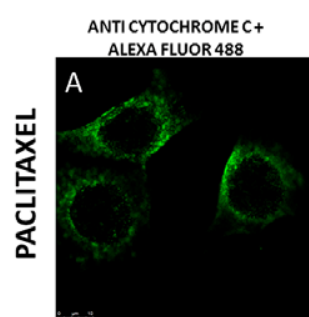

RED MITOTRACKER
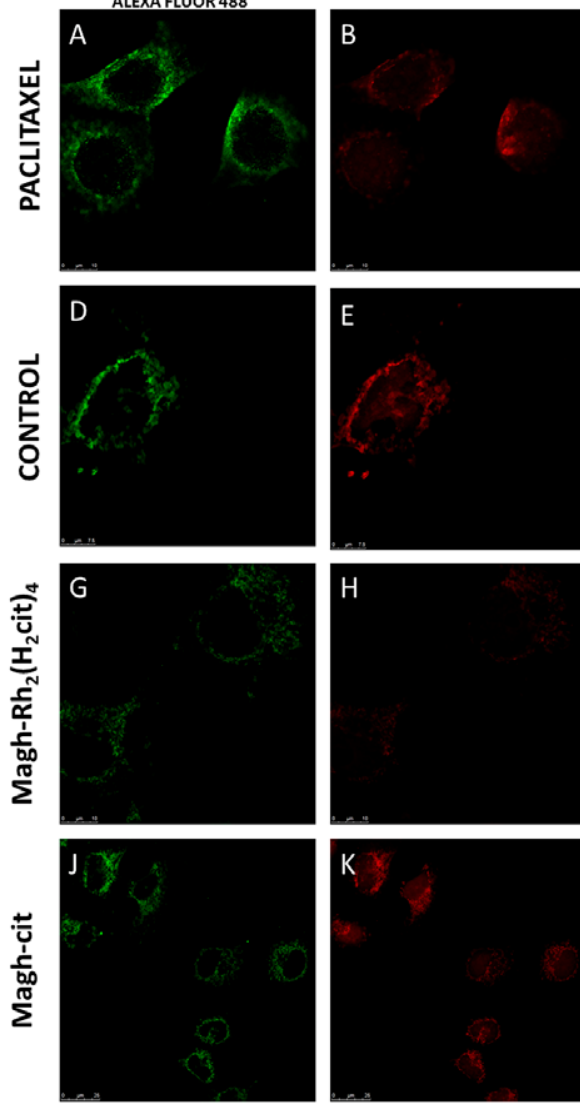
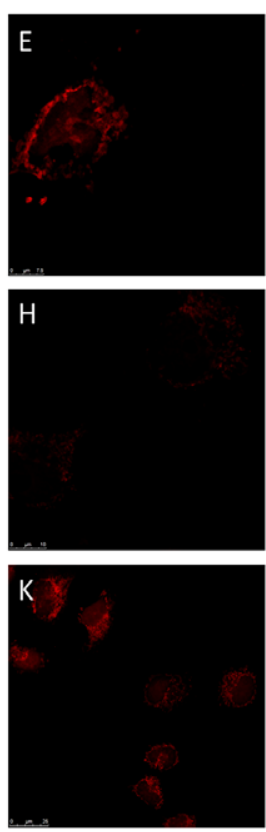

OVERLAY AND DAPI (NUCLEI)
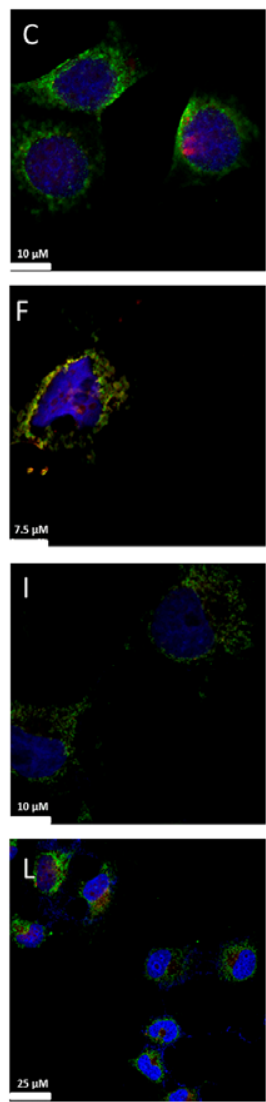

Notes: Right columns show the scale bars.

Figure 5: Cell localization assay for mitochondria and cytochrome $\mathrm{C}$ : The identification of cytochrome $C(A, D, G$ and $J)$ was performed by labeling with anti-cytochrome $\mathrm{C}$ primary antibody and revealed with a secondary antibody (Alexa-fluor 488 green). Mitochondria were marked with Red-mitotracker (B, $\mathrm{E}$ $\mathrm{H}$ and $\mathrm{K}$ ). Nuclei were labelled with DAPI in blue (C, F, I, L). MCF-7 cells were treated with $10 \mathrm{nM}$ paclitaxel for two hours $(\mathrm{A}, \mathrm{B}$ and $\mathrm{C})$ as the positive control group. Untreated cells formed the control group ( $D, E$ and $F)$. The treatment was evaluated with $300 \mu \mathrm{M} \mathrm{Rh}{ }_{2}\left(\mathrm{H}_{2} \mathrm{cit}\right)_{4}$-loaded maghemite NPs [Magh-Rh $\left.\mathrm{H}_{2} \mathrm{H}_{2} \mathrm{cit}\right)$ ( $\mathrm{G}, \mathrm{H}$ and $\mathrm{I}$ ) or $0.019 \mathrm{~mol} / \mathrm{L}$ (iron) maghemite nanoparticles loaded with citrate (Magh-cit) ( $\mathrm{J}, \mathrm{K}$ and $\mathrm{L}$ ). The translocation of cytochrome $\mathrm{C}$ is evidenced in the overlay images $(\mathrm{C}, \mathrm{F}, \mathrm{I}$ and $\mathrm{L})$.

to normal breast epithelial cells. However, these nanoparticles (Maghcit) form precipitates in culture medium (DMEM) earlier than Magh$\mathrm{Rh}_{2}\left(\mathrm{H}_{2} \mathrm{cit}\right)_{4}$. The formation of aggregates in media is an obstacle to the employment of magnetic nanoparticles for in vitro and in vivo tests $[34,35]$. Thus, Magh-cit was less stable than Magh- $\mathrm{Rh}_{2}\left(\mathrm{H}_{2} \mathrm{cit}\right)_{4}$ for our analyses.

It has been suggested that the physicochemical properties of $\mathrm{Rh}_{2}\left(\mathrm{H}_{2} \mathrm{cit}\right)_{4}$-loaded maghemite NPs should be promising for use in cancer treatment [30]. The metal complexes analyzed, in the present work, were shown to be anionic. This characteristic can be related to a high affinity for cellular membrane in a few cationic sites, similarly to what may occur in the adsorption of anionic ferritin [36-39].

The monodispersity feature observed in the nanoparticles of this work was also found in other studies on the characterization of maghemite nanoparticles without using any size selection tool $[40,41]$. This feature is a key property for the production of nanoparticles for biomedical applications. Polydispersity indexes like those recorded in this analysis (monodisperse), reflect the narrow distribution of nanoparticle sizes and homogeneity, indicating a high level of complex diameter control.

In the cytotoxicity evaluation, we observed that free $\mathrm{Rh}_{2}\left(\mathrm{H}_{2} \mathrm{cit}\right)_{4}$ at concentrations of up to $300 \mu \mathrm{M}$ did not significantly reduce breast cancer cells' viability. Carneiro and co-workers [30] obtained similar results for the same complex and concentrations after 24 and 48 hours treatments in MCF-7 cells (viability of $85 \%$ and $73 \%$, respectively). However, when combining $\mathrm{Rh}_{2}\left(\mathrm{H}_{2} \mathrm{cit}\right)_{4}$ with maghemite nanoparticles, a higher reduction in tumor cell viability was observed than with the free complex. The number of non-viable cells was higher in tumor cells (MCF-7) than in normal cells (MCF-10A), particularly at the concentrations of $200 \mu \mathrm{M}$ and $300 \mu \mathrm{M}$ (after 24 hours). Similarly, in our work, which compared $50 \mu \mathrm{M}$ rhodium citrate free or associated with nanoparticles $\left(3 \times 10^{15}\right.$ iron particles $\left./ \mathrm{ml}\right)$, the association with maghemite nanoparticles enhanced the cytotoxic action of rhodium citrate. Moreover, for the same iron concentration, there have not been reports of viability reduction promoted by maghemite nanoparticles functionalized with citrate only (Magh-cit) for the strains tested for 24, 48 and 72 hours [30]. In the present study, a cytotoxic action of this nanoparticle was demonstrated, which was higher in MCF-7 cells than in the untreated cells after 24 hours of treatment at a concentration of $19 \mathrm{mM}$ iron $\left(2.4 \times 10^{16}\right.$ particles of iron $/ \mathrm{ml}$ ). However, this cytotoxicity was not statistically different from the values found for $\mathrm{Magh}-\mathrm{Rh}_{2}\left(\mathrm{H}_{2} \mathrm{cit}\right)_{4}$ and, as already mentioned, (Magh-cit) was less stable in culture medium, hindering its application. The cytotoxicity promoted by Magh-cit in MCF7 , in this study, could be attributed to the greater number of iron particles/ml $\left(2.4 \times 10^{16}\right)$ found in our compound compared to the nanoparticles used in the study by Carneiro and colleagues [30].

Even being biocompatible, compounds containing iron can be associated with cellular cytotoxicity mediated mainly by redox mechanisms that cause oxidative stress $[42,43]$. The tests for ROS production by tumor cells treated with our metal compounds showed that oxidative stress may be the initial signal that induces cell death after one and a half hours of treatment. On the other hand, there was not

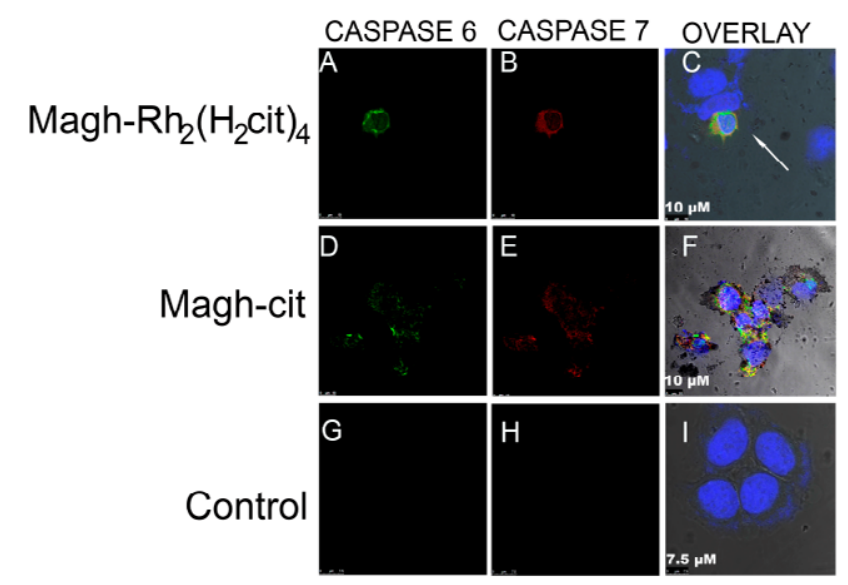

Notes: Right columns show the scale bars.

Figure 6: Activation of caspases: In cells treated with $300 \mu \mathrm{M} \mathrm{Rh}\left(\mathrm{H}_{2} \mathrm{cit}\right)_{4}^{-}$ loaded maghemite NPs [Magh- $\mathrm{Rh}_{2}\left(\mathrm{H}_{2} \mathrm{cit}\right)_{4}$ ] and $0.019 \mathrm{~mol} / \mathrm{L}$ (iron) maghemite nanoparticles loaded with citrate (Magh-cit), active caspases 6 (shown in green) and 7 (red fluorescence) were identified after 12 hours of treatment. By overlapping brightfield and fluorescence images, the pyknotic nuclei is indicated by an arrow, which is characteristic of apoptosis. In the control group, only the nuclei of MCF-7 cells were labeled with DAPI (blue fluorescence). 
Citation: Chaves NL, Lopes CAP, Carneiro MLB, Souza ARD, Silva MOD, et al. (2015) Rhodium Citrate Associated with Maghemite Nanoparticles Causes DNA Fragmentation Independently of Caspases 3 and Mediated by Reactive Oxygen Species. J Nanomed Nanotechnol 6: 312. doi:10.4172/2157-7439.1000312
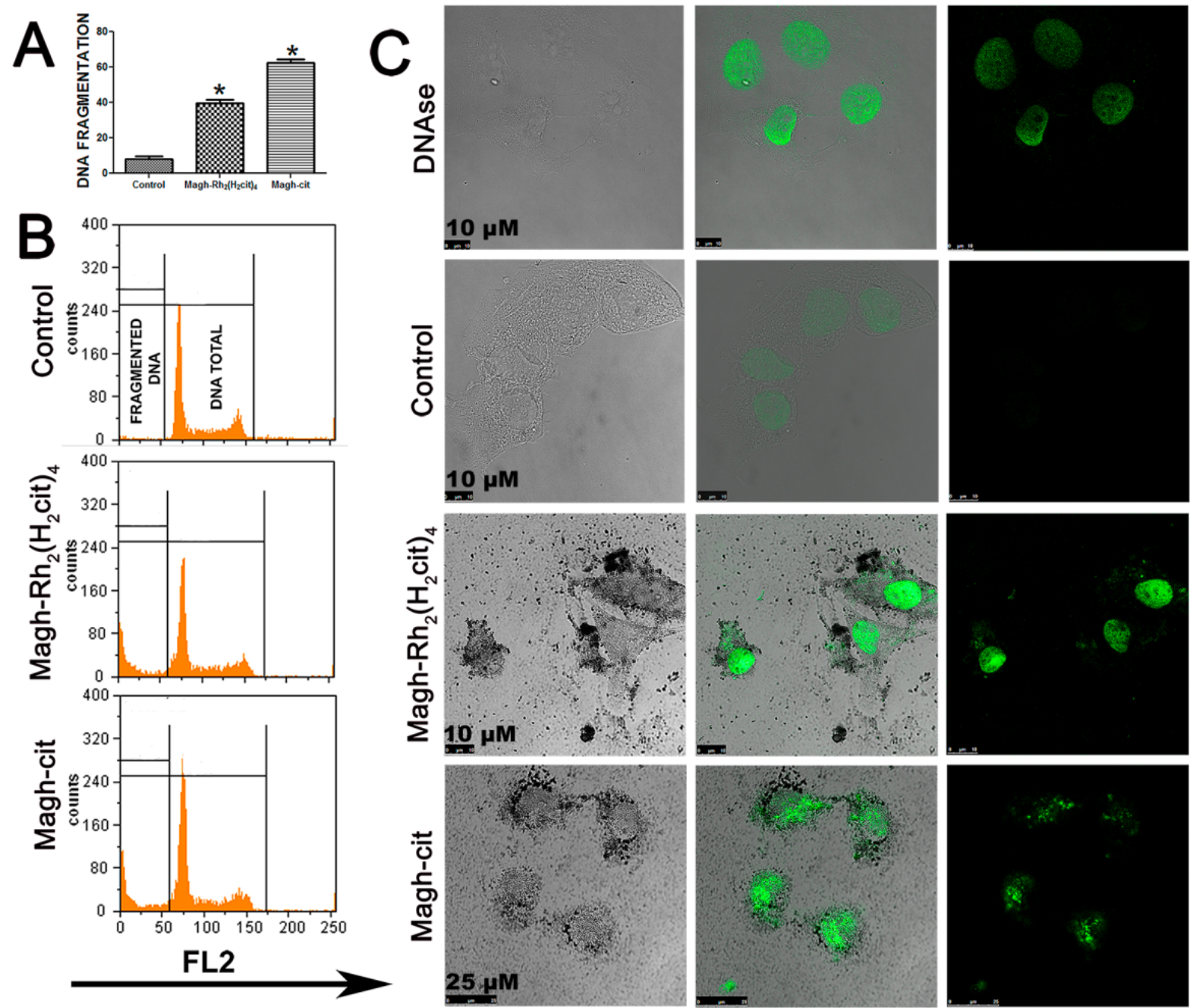

Figure 7: DNA fragmentation in MCF-7 cells: The cells were treated with $300 \mu \mathrm{M} \mathrm{Rh}\left(\mathrm{H}_{2}\right.$ cit) -loaded maghemite $\mathrm{NPs}\left[\mathrm{Magh}-\mathrm{Rh} \mathrm{H}_{2}\left(\mathrm{H}_{2} \mathrm{cit}\right)\right.$.] or $0.019 \mathrm{~mol} / \mathrm{L}$ (iron) maghemite nanoparticles loaded with citrate (Magh-cit) for 36 hours for quantification of DNA fragmentation by flow cytometry (A). Statistical analysis of the mean difference between the groups was determined by two-way analysis of variance (ANOVA) followed by the Bonferroni's post hoc test $(*)$ : $P<0.05$. Fragmented DNA is identified in the sub GO/G1 peak (Sub-G1) after labeling with propidium iodide (FL2) by flow cytometry. Intact DNA is shown in DNA total gating (B). Laser scanning confocal microscopy of cells subjected to the TUNEL assay (C). The DNA fragmentation was determined by treatment with $10 \mathrm{U} / \mathrm{ml}$ DNAse (positive control). The MCF-7 cells were treated with $300 \mu \mathrm{M}$ Magh- $\mathrm{Rh}_{2}\left(\mathrm{H}_{2} \text { cit) }\right)_{4}$ or $0.019 \mathrm{~mol} / \mathrm{L}$ (iron) Magh-cit for 24 hours. In the control group, cells did not receive any treatment. Notes: Left columns show the scale bars.

any increased production of ROS in Magh-cit treated cells as compared to the control sample and the other groups, indicating that these two nanoparticles can induce cell death by different mechanisms, or that Magh-cit is not being internalized by the cell in the same manner as Magh- $\mathrm{Rh}_{2}\left(\mathrm{H}_{2} \mathrm{cit}\right)_{4}$. The size of the nanoparticles or clusters formed by them is strongly associated with cellular uptake and death induction mechanisms [44-46]. Studies of colloidal stability of these kinds of nanoparticles showed changes in stability and a tendency for the formation of clusters associated with $\mathrm{pH}$ and ion concentration in the culture medium [47]. Although a general description is still missing, it is believed that the colloidal destabilization of Magh-cit in biological fluids results from the adsorption of biological molecules, but also from the exchange and/or the removal of the protecting layer. As a result, the original coating is not sufficient to offset the van der Waals attraction, which leads to aggregation, as demonstrated in the study by Safi and colleagues [48].
Another candidate for the cellular damage caused by the nanoparticles is the loading component, citric acid. Citrate is formed by condensation of acetyl-coenzyme A and oxaloacetate and plays a key role in the regulation of glycolysis. Thus, it may be related to cytotoxic activity in tumor cells that exhibit an increased anaerobic glycolysis $[49,50]$. In accordance with the findings of Zhang and co-workers [51], who reported that citrate may exert a cytotoxic effect on mesothelioma MSTO- $211 \mathrm{H}$ cultured cells, this molecule can be important not only to functionalize nanoparticles, but also to exert a synergistic effect on the cytotoxicity in tumor cells.

Finally, we also found that rhodium citrate associated with maghemite nanoparticles induces death in breast cancer cells with active caspases and DNA fragmentation. From our cell model, it was easy to determine that such cell death occurs independently of caspase 3 activation. Nevertheless, other effector caspases may be involved in this process [52]. 
Citation: Chaves NL, Lopes CAP, Carneiro MLB, Souza ARD, Silva MOD, et al. (2015) Rhodium Citrate Associated with Maghemite Nanoparticles Causes DNA Fragmentation Independently of Caspases 3 and Mediated by Reactive Oxygen Species. J Nanomed Nanotechnol 6: 312. doi:10.4172/2157-7439.1000312

Page 8 of 10

The compounds Magh- $\mathrm{Rh}_{2}\left(\mathrm{H}_{2} \mathrm{cit}\right)_{4}$ and Magh-cit at the concentrations of $300 \mu \mathrm{M}$ (rhodium citrate) and $19 \mathrm{mM}$ (iron), respectively, induced cytochrome $\mathrm{C}$ release after 24 hours. This event is characteristic of apoptotic cell death via the mitochondrial pathway. The activation and dispersion of cytochrome $\mathrm{C}$ is an initial stage of the apoptosis process, which results from the alteration of the mitochondrial membrane potential [53]. Although the type of tumor cell tested (MCF-7) does not express caspase 3, which characterizes it as a cell resistant to apoptosis [54], apoptosis in MCF-7 cells has already been described, induced by several compounds, including other DNA damaging agents. Xue and colleagues [55] observed that staurosporine induces apoptosis in this cell type, but not all mitochondrial changes inherent to this process were always present [56].

It was shown that cytochrome $\mathrm{C}$ release could be independent of caspases activation [57]. It was further noted that caspase 8 can also cleave Bid ( $\mathrm{BH} 3$ domain-containing proapoptotic members of the Bcl-2 family) to their truncated form (tBid). Translocation of tBid to mitochondria induces mitochondrial release of cytochrome $\mathrm{C}$ and subsequent caspase 9 activation, thus amplifying the death signal [58]. Our model excludes any relationship between the mechanism involved in cytochrome $\mathrm{C}$ release from mitochondria and caspase 3 activation induced by Magh- $\mathrm{Rh}_{2}\left(\mathrm{H}_{2} \mathrm{cit}\right)_{4}$ and Magh-cit.

In addition to the cytochrome $\mathrm{C}$ release, caspases (6 and 7) activation, another apoptosis marker, was found following treatment for 12 hours with $300 \mu \mathrm{M}$ Magh- $\mathrm{Rh}_{2}\left(\mathrm{H}_{2} \text { cit }\right)_{4}$ and $19 \mathrm{mM}$ (iron) Magh-cit. The caspases, proteases of the cysteine family, are the main components of the execution phase of the programmed cell death. The initiator caspases $(2,8,9$ and 10) are first induced to oligomerization, leading to autocatalytic activity and subsequent cleavage of effector caspases [53]. In the pathway initiated by caspase 9 , cytoplasmic cytochrome $\mathrm{C}$ triggers apoptosome formation, which is a multi-protein complex containing cytochrome C, dATP, Apaf-1 (Apoptotic protease-activating factor 1 ) and pro-caspase $9[58,59]$. It has already been reported that besides cytochrome $\mathrm{C}$ release from mitochondria, effector caspase activation (caspase 7) was also observed after ultraviolet radiation treatment of MCF-7 cells [60]. Since MCF-7 cells were induced morphologically and physiologically to cell death by apoptosis, it is suggested that there is an alternative pathway to apoptosis initiation. It has been proposed that initiator caspases with long pro-domains, such as caspases 8 or 9 , can lead to the induction of apoptosis by activating effector caspases other than caspase 3 , such as caspase $7[61,62]$. Along with caspase 7 , another important component of the apoptosis cascade is caspase 6, which was also identified in its active form in this work. Caspase 6 is responsible for cleaving nuclear lamins, thus triggering cell death [63]. Inhibition of caspase 6 protects MCF-7 cells from apoptosis induced by the anti-mitotic agent neocarzinostati [64]. Therefore, identification of activated effector caspases 6 and 7 in our studies allows us to consider them important candidate mediators of apoptotic changes resulting from treatment with Magh- $\mathrm{Rh}_{2}\left(\mathrm{H}_{2} \mathrm{cit}\right)_{4}$ and Magh-cit. Nevertheless, this hypothesis requires confirmatory testing, such as analysis of these events after inhibition of these caspases.

Nuclear DNA degradation in nucleosomes is a characteristic of cell death by apoptosis. This process occurs in response to various apoptotic stimuli in a wide variety of cell types [65]. Molecular characterization of this process has identified a specific DNAse (CAD, caspase-activated DNase), which cleaves the chromosomal DNA in a caspase-dependent manner. CAD is synthesized with the help of ICAD (inhibitor of CAD), which functions as a specific chaperone for CAD. This DNAse is found complexed with ICAD in cell proliferation. When cells are induced to apoptosis, caspases, especially caspase 3 , cleaves ICAD, which leads to the dissociation of the CAD-ICAD complex and the release of CAD to cleave the chromosomal DNA $[26,66]$. Ultraviolet radiation, staurosporine, tumor necrosis factor (TNF) and several other DNA damaging agents are listed as inducers of apoptosis in MCF-7 cells $[67,68]$. However, in these studies, death occurred in the absence of DNA fragmentation. According to Jänicke [54], caspase 3 activation is essential to the occurrence of this particular event. Conversely, in our studies, maghemite nanoparticles loaded with rhodium citrate or only citrate were able to induce DNA fragmentation in MCF-7 cells as observed in DNA analysis by flow cytometry, which was complemented by morphological analyses provided by the TUNEL assay. It was also demonstrated that DNA fragmentation occurred by the TUNEL labeling method in this cellular type, after treatment with Pbox-6, a member of pyrrolo-1,5-benzoxazepines [27]. These investigators demonstrated that DNA fragmentation was suppressed by caspase 7 inhibition, suggesting that, in the absence of caspase 3, another effector caspase may be the primary mediator of DNA fragmentation. This may also be the explanation for the mechanism of DNA fragmentation induced by Magh- $\mathrm{Rh}_{2}\left(\mathrm{H}_{2} \mathrm{cit}\right)_{4}$ and Magh-cit in MCF-7 cells. Liang and colleagues [64] also observed DNA fragmentation in MCF-7 cells after neocarzinostatin treatment. Using a number of caspase inhibitors with overlapping specificities, specific chromogenic enzyme substrates and an antibody specific for activated caspase 7 , this group concluded that, for the treatment tested in this strain, the occurrence of apoptosis is dependent on caspases 9, 7 and 6 .

Besides the hypothesis of other effector caspases as mediators of DNA fragmentation, some studies support the induction of apoptosis by a caspase- independent pathway [69,70]. In tests with resveratrol (RES), a chemopreventive molecule, DNA fragmentation was observed in MCF-7 cells, even with the inhibition of caspases, thus suggesting a caspase-independent mechanism of apoptosis. This process is mediated by $\mathrm{Bcl}-2$, which promotes a loss of mitochondrial membrane potential and increased production of reactive oxygen species (ROS) [70]. This pathway is a plausible hypothesis to explain the mechanism of death caused by Magh- $\mathrm{Rh}_{2}\left(\mathrm{H}_{2} \mathrm{cit}\right)_{4}$ in MCF-7 cells, since these latter events were also evidenced in the present study.

\section{Conclusion}

The pattern of cell death features in the absence of caspases demonstrated in our work suggests an atypical activation of apoptosis in MCF-7. Therefore, the mechanisms of DNA fragmentation, as well as apoptosis signaling cascade events induced by $\mathrm{Magh}-\mathrm{Rh}_{2}\left(\mathrm{H}_{2} \mathrm{cit}\right)_{4}$ and Magh-cit must be further investigated in order to elucidate their cytotoxic action. The data generated by this work may contribute to the development of these nanoparticles as increasingly effective compounds for the treatment of breast cancer. Further studies are being conducted in our lab in order to better understand the mechanism involved in cell death induced by Magh- $\mathrm{Rh}_{2}\left(\mathrm{H}_{2} \mathrm{cit}\right)_{4}$ and Magh-cit.

\section{Competing Interests}

The authors declare that they have no competing interests.

\section{Authors' Contributions}

NLC was the principal investigator and takes primary responsibility for the paper. NLC, CAPL, MLBC and JRC and SNB participated in the design of the study and SNB coordinated the research; NLC performed the laboratory work for this study; MORS and ARS synthesized the rhodium citrate and rhodium citrateloaded nanoparticles; All authors contributed equally to the writing and editing of this article and approved the final manuscript. 
Citation: Chaves NL, Lopes CAP, Carneiro MLB, Souza ARD, Silva MOD, et al. (2015) Rhodium Citrate Associated with Maghemite Nanoparticles Causes DNA Fragmentation Independently of Caspases 3 and Mediated by Reactive Oxygen Species. J Nanomed Nanotechnol 6: 312. doi:10.4172/2157-7439.1000312

Page 9 of 10

\section{Acknowledgments}

This research was supported by the National Council for Scientific and Technological Development (CNPq), Coordination for the Improvement of Higher Education Personnel (CAPES), Foundation for Research Support in the Federa District (FAP-DF), Financier of Studies and Projects (FINEP) and the National Institute of Science and Technology (INCT) in Nanobiotechnology (MCTI).

\section{References}

1. Chifotides HT, Dunbar KR (2005) Interactions of metal-metal-bonded antitumor active complexes with DNA fragments and DNA. Acc Chem Res 38: 146-156.

2. Florea AM, Büsselberg D (2011) Cisplatin as an anti-tumor drug: cellular mechanisms of activity, drug resistance and induced side effects. Cancers (Basel) 3: 1351-1371

3. Kanapathipillai M, Brock A, Ingber DE (2014) Nanoparticle targeting of anti-cancer drugs that alter intracellular signaling or influence the tumor microenvironment. Advanced Drug Delivery Reviews 79: 107-118.

4. Alexis F, Rhee JW, Richie JP, Radovic-Moreno AF, Langer R, et al. (2008) New frontiers in nanotechnology for cancer treatment. Urol Oncol 26: 74-85.

5. Cole AJ, Yang VC, David AE (2011) Cancer theranostics: the rise of targeted magnetic nanoparticles. Trends Biotechnol 29: 323-332.

6. Mirzakhalili E, Gourgou E, Epureanu B (2015) Transport by a Kinesin in the Presence of Magnetic Nanoparticles. Biophysical Journal 108: 137a.

7. Pankhurst QA, Connolly J, Jones S, Dobson J (2003) Applications of magnetic nanoparticles in biomedicine. Journal of physics D: Applied physics 36: R167.

8. Laurent S, Dutz S, Häfeli UO, Mahmoudi M (2011) Magnetic fluid hyperthermia: focus on superparamagnetic iron oxide nanoparticles. Adv Colloid Interface Sci 166: 8-23.

9. Mahmoudi K, Hadjipanayis CG (2014) The application of magnetic nanoparticles for the treatment of brain tumors. Front Chem 2: 109.

10. Buzdar AU, Ibrahim NK, Francis D, Booser DJ, Thomas ES, et al. (2005) Significantly higher pathologic complete remission rate after neoadjuvant therapy with trastuzumab, paclitaxel, and epirubicin chemotherapy: results of a randomized trial in human epidermal growth factor receptor 2-positive operable breast cancer. Journal of Clinical Oncology 23: 3676-3685

11. Jemal A, Bray F, Center MM, Ferlay J, Ward E, et al. (2011) Global cancer statistics. CA Cancer J Clin 61: 69-90.

12. Dellapasqua S, Bagnardi V, Regan MM, Rotmensz N, Mastropasqua MG, et al. (2012) A risk score based on histopathological features predicts higher risk of distant recurrence in premenopausal patients with lymph node-negative endocrine-responsive breast cancer. The Breast 21: 621-628

13. Sinha K, Das J, Pal PB, Sil PC (2013) Oxidative stress: the mitochondriadependent and mitochondria-independent pathways of apoptosis. Arch Toxicol 87: $1157-1180$

14. Keswani T, Chowdhury S, Mukherjee S, Bhattacharyya A (2014) Palladium (II) complex induces apoptosis through ROS-mediated mitochondrial pathway in human lung adenocarcinoma cell line (A549). Current Science 107: 1711.

15. Chiara F, Gambalunga A, Sciacovelli M, Nicolli A, Ronconi L, et al. (2012) Chemotherapeutic induction of mitochondrial oxidative stress activates GSK$3 a / \beta$ and Bax, leading to permeability transition pore opening and tumor cell death. Cell Death \& Disease 3: e444.

16. Chen F, Vallyathan V, Castranova V, Shi X (2001) Cell apoptosis induced by carcinogenic metals. Mol Cell Biochem 222: 183-188.

17. Sun KW, Ma YY, Guan TP, Xia YJ, Shao CM, et al. (2012) Oridonin induces apoptosis in gastric cancer through Apaf-, cytochrome $c$ and caspase-3 signaling pathway. World J Gastroenterol 18: 7166-7174.

18. Lowe SW, Lin AW (2000) Apoptosis in cancer. Carcinogenesis 21: 485-495.

19. Alexander S, Friedl P (2012) Cancer invasion and resistance: interconnected processes of disease progression and therapy failure. Trends Mol Med 18 13-26.

20. Cairns RA, Harris IS, Mak TW (2011) Regulation of cancer cell metabolism. Nat Rev Cancer 11: 85-95.

21. Sayers TJ (2011) Targeting the extrinsic apoptosis signaling pathway for cancer therapy. Cancer Immunol Immunother 60: 1173-1180.
22. Thornberry NA, Lazebnik Y (1998) Caspases: enemies within Science 281: 1312-1316.

23. Marzo I, Susin SA, Petit PX, Ravagnan L, Brenner C, et al. (1998) Caspases disrupt mitochondrial membrane barrier function. FEBS Lett 427: 198-202.

24. Sebbagh M, Renvoizé C, Hamelin J, Riché N, Bertoglio J, et al. (2001) Caspase-3-mediated cleavage of ROCK I induces MLC phosphorylation and apoptotic membrane blebbing. Nat Cell Biol 3: 346-352.

25. Fischer U, Jänicke RU, Schulze-Osthoff K (2003) Many cuts to ruin: a comprehensive update of caspase substrates. Cell Death Differ 10: 76-100.

26. Nagata S (2000) Apoptotic DNA fragmentation. Exp Cell Res 256: 12-18.

27. Mc Gee MM, Hyland E, Campiani G, Ramunno A, Nacci V, et al. (2002) Caspase-3 is not essential for DNA fragmentation in MCF-7 cells during apoptosis induced by the pyrrolo-,5-benzoxazepine, PBOX-6. FEBS Lett 515: 66-70.

28. Oberhammer F, Wilson JW, Dive C, Morris ID, Hickman JA, et al. (1993) Apoptotic death in epithelial cells: cleavage of DNA to 300 and/or $50 \mathrm{~kb}$ fragments prior to or in the absence of internucleosomal fragmentation. EMBO J 12: 3679-3684

29. Cui Q, Yu JH, Wu JN, Tashiro S, Onodera S, et al. (2007) P53-mediated cel cycle arrest and apoptosis through a caspase-3- independent, but caspase9-dependent pathway in oridonin-treated MCF-7 human breast cancer cells. Acta Pharmacol Sin 28: 1057-1066.

30. Carneiro ML, Nunes ES, Peixoto RC, Oliveira RG, Lourenço LH, et al. (2011) Free Rhodium (II) citrate and rhodium (II) citrate magnetic carriers as potential strategies for breast cancer therapy. J Nanobiotechnology 9: 11

31. Perlstein B, Ram Z, Daniels D, Ocherashvilli A, Roth Y, et al. (2008) Convectionenhanced delivery of maghemite nanoparticles: Increased efficacy and MRI monitoring. Neuro Oncol 10: 153-161.

32. Carneiro ML, Peixoto RC, Joanitti GA, Oliveira RG, Telles LA et al (2013) Antitumor effect and toxicity of free rhodium (II) citrate and rhodium (II) citrate-loaded maghemite nanoparticles in mice bearing breast cancer. J Nanobiotechnology 11: 4

33. Štarha P, Stavárek M, Tucek J, Trávnícek Z (2014) 4-Aminobenzoic AcidCoated Maghemite Nanoparticles as Potential Anticancer Drug Magnetic Carriers: A Case Study on Highly Cytotoxic Cisplatin-Like Complexes Involving 7-Azaindoles. Molecules 19: 1622-1634

34. Keller AA, Wang H, Zhou D, Lenihan HS, Cherr G, et al. (2010) Stability and aggregation of metal oxide nanoparticles in natural aqueous matrices. Environ Sci Technol 44: 1962-1967.

35. Oostingh GJ, Casals E, Italiani P, Colognato R, Stritzinger R, et al. (2011) Problems and challenges in the development and validation of human cellbased assays to determine nanoparticle-induced immunomodulatory effects. Part Fibre Toxicol 8: 8.

36. Wilhelm C, Billotey C, Roger J, Pons JN, Bacri JC, et al. (2003) Intracellular uptake of anionic superparamagnetic nanoparticles as a function of their surface coating. Biomaterials 24: 1001-1011.

37. Sokolova V, Kozlova D, Knuschke T, Buer J, Westendorf AM, et al. (2013) Mechanism of the uptake of cationic and anionic calcium phosphate nanoparticles by cells. Acta Biomater 9: 7527-7535

38. Vaccari CB, Cerize NN, Morais PC, Ré MI, Tedesco AC (2012) Biocompatible magnetic microspheres for Use in PDT and hyperthermia. J Nanosci Nanotechnol 12: 5111-5116.

39. Brar SK, Verma M (2011) Measurement of nanoparticles by light-scattering techniques. TrAC Trends in Analytical Chemistry 30: 4-17.

40. Hyeon T, Lee SS, Park J, Chung Y, Na HB (2001) Synthesis of highly crystalline and monodisperse maghemite nanocrystallites without a size-selection process. Journal of the American Chemical Society 123: 12798-12801.

41. Vidal-Vidal J, Rivas J, Lopez-Quintela M (2006) Synthesis of monodisperse maghemite nanoparticles by the microemulsion method. Colloids and Surfaces A: Physicochemical and Engineering Aspects 288: 44-51.

42. Jungwirth U, Kowol CR, Keppler BK, Hartinger CG, Berger W, et al. (2011) Anticancer activity of metal complexes: involvement of redox processes. Antioxid Redox Signal 15: 1085-1127.

43. Auffan M, Achouak W, Rose J, Roncato MA, Chanéac C, et al. (2008) Relation between the redox state of iron-based nanoparticles and their cytotoxicity toward Escherichia coli. Environ Sci Technol 42: 6730-6735. 
Citation: Chaves NL, Lopes CAP, Carneiro MLB, Souza ARD, Silva MOD, et al. (2015) Rhodium Citrate Associated with Maghemite Nanoparticles Causes DNA Fragmentation Independently of Caspases 3 and Mediated by Reactive Oxygen Species. J Nanomed Nanotechnol 6: 312. doi:10.4172/2157-7439.1000312

Page 10 of 10

44. Jiang W, Kim BY, Rutka JT, Chan WC (2008) Nanoparticle-mediated cellular response is size-dependent. Nat Nanotechnol 3: 145-150.

45. Clift MJ, Rothen-Rutishauser B, Brown DM, Duffin R, Donaldson K, et al. (2008) The impact of different nanoparticle surface chemistry and size on uptake and toxicity in a murine macrophage cell line. Toxicol Appl Pharmacol 232: 418 427

46. Albanese A, Chan WC (2011) Effect of gold nanoparticle aggregation on cell uptake and toxicity. ACS Nano 5: 5478-5489.

47. Da Silva Nunes E, Carneiro MLB, de Oliveira RGS, Báo SN, de Souza AR (2013) Colloidal stability, surface characterisation and intracellular accumulation of Rhodium (II) citrate coated superparamagnetic iron oxide nanoparticles in breast tumour: a promising platform for cancer therapy. Journal of Nanoparticle Research 15: 1-15.

48. Safi M, Courtois J, Seigneuret M, Conjeaud H, Berret JF (2011) The effects of aggregation and protein corona on the cellular internalization of iron oxide nanoparticles. Biomaterials 32: 9353-9363.

49. Stryer L (1989) Molecular design of life. WH Freeman.

50. Warburg O (1956) On the origin of cancer cells. Science 123: 309-314.

51. Zhang X, Varin E, Allouche S, Lu Y, Poulain L, et al. (2009) Effect of citrate on malignant pleural mesothelioma cells: a synergistic effect with cisplatin. Anticancer Res 29: 1249-1254

52. Kumar S (2007) Caspase function in programmed cell death. Cell Death Differ 14: $32-43$.

53. Slee EA, Harte MT, Kluck RM, Wolf BB, Casiano CA, et al. (1999) Ordering the cytochrome c-initiated caspase cascade: hierarchical activation of caspases-2, -3 , $-6,-7,-8$, and -10 in a caspase-9-dependent manner. J Cell Biol 144: 281-292.

54. Jänicke RU (2009) MCF-7 breast carcinoma cells do not express caspase-3. Breast Cancer Res Treat 117: 219-221.

55. Xue L, Chiu S, Oleinick NL (2003) Staurosporine-induced death of MCF-7 human breast cancer cells: a distinction between caspase-3-dependent steps of apoptosis and the critical lethal lesions. Experimental Cell Research 283 $135-145$

56. Slee EA, Adrain C, Martin SJ (2001) Executioner caspase-3, -6, and -7 perform distinct, non-redundant roles during the demolition phase of apoptosis. J Bio Chem 276: 7320-7326.

57. Narvaez CJ, Welsh J (2001) Role of mitochondria and caspases in vitamin D-mediated apoptosis of MCF-7 breast cancer cells. J Biol Chem 276: 9101-9107.
58. Li P, Nijhawan D, Budihardjo I, Srinivasula SM, Ahmad M, et al. (1997) Cytochrome $c$ and dATP-dependent formation of Apaf-1/caspase-9 complex initiates an apoptotic protease cascade. Cell 91: 479-489.

59. Saleh A, Srinivasula SM, Acharya S, Fishel R, Alnemri ES (1999) Cytochrome c and dATP-mediated oligomerization of Apaf- 1 is a prerequisite for procaspase- 9 activation. J Biol Chem 274: 17941-17945.

60. Ferguson HA, Marietta PM, Van Den Berg CL (2003) UV-induced apoptosis is mediated independent of caspase- 9 in MCF-7 cells: a model for cytochrome c resistance. J Biol Chem 278: 45793-45800.

61. Fraser A, Evan G (1996) A license to kill. Cell 85: 781-784.

62. Cohen GM (1997) Caspases: the executioners of apoptosis. Biochem J 326: 1-16.

63. Orth K, Chinnaiyan AM, Garg M, Froelich CJ, Dixit VM (1996) The CED-3/ ICE-like protease Mch2 is activated during apoptosis and cleaves the death substrate lamin A. J Biol Chem 271: 16443-16446.

64. Liang Y, Yan C, Schor NF (2001) Apoptosis in the absence of caspase 3. Oncogene 20: 6570-6578.

65. Enari M, Sakahira H, Yokoyama H, Okawa K, Iwamatsu A, et al. (1998) A caspase-activated DNase that degrades DNA during apoptosis, and its inhibitor ICAD. Nature 391: 43-50.

66. Sakahira H, Enari M, Nagata S (1998) Cleavage of CAD inhibitor in CAD activation and DNA degradation during apoptosis. Nature 391: 96-99.

67. Jänicke RU, Sprengart ML, Wati MR, Porter AG (1998) Caspase-3 is required for DNA fragmentation and morphological changes associated with apoptosis. J Biol Chem 273: 9357-9360

68. Jänicke RU, Engels IH, Dunkern T, Kaina B, Schulze-Osthoff K, et al. (2001) lonizing radiation but not anticancer drugs causes cell cycle arrest and failure to activate the mitochondrial death pathway in MCF-7 breast carcinoma cells Oncogene 20: 5043-5053.

69. Fehsel K, Kröncke KD, Meyer KL, Huber H, Wahn V, et al. (1995) Nitric oxide induces apoptosis in mouse thymocytes. J Immunol 155: 2858-2865.

70. Pozo-Guisado E, Merino JM, Mulero-Navarro S, Lorenzo-Benayas MJ Centeno F, et al. (2005) Resveratrol-induced apoptosis in MCF-7 human breast cancer cells involves a caspase-independent mechanism with downregulation of Bcl-2 and NF-kappaB. International Journal of Cancer 115: 74-84. 